\title{
Middle to late Wisconsinan climate and ecological changes in northern Alaska: Evidences from the Itkillik River Yedoma
}

\author{
Lyna Lapointe E. a,b,* Julie Talbot ${ }^{\text {a }}$, Daniel Fortier ${ }^{\text {a,b }}$, Bianca Fréchette ${ }^{\mathrm{c}}$, Jens Strauss ${ }^{\mathrm{d}}$, \\ Mikhail Kanevskiy ${ }^{\mathrm{e}}$, Yuri Shur ${ }^{\mathrm{e}}$ \\ a Department of Geography, Université de Montréal, Montréal, 520 Chemin de la Côte-Sainte-Catherine, Outremont, QC H2V 2B8, Canada \\ b Center for Northern Studies, Université Laval, 2405, rue de la Terrasse, Québec, QC G1V 0A6, Canada \\ c Geotop Research Centre on the Dynamics of the Earth System, Université du Québec à Montréal, 201 Avenue du Président-Kennedy, Montréal, QC H2X 3Y7, Canada \\ d Alfred Wegener Institute Helmholtz Centre for Polar and Marine Research, Research Unit Potsdam, Telegrafenberg A45, 14471 Potsdam, Germany \\ e Institute of Northern Engineering, University of Alaska Fairbanks, 306 Tanana Loop, Fairbanks, AK 99775-5910, USA
}

\section{A R T I C L E I N F O}

Article history:

Received 21 March 2017

Received in revised form 31 July 2017

Accepted 2 August 2017

Available online $\mathrm{xxxx}$

\section{Keywords:}

Paleoclimate

Paleoecology

Syngenetic permafrost

Wisconsinan glaciation

Beringia

Arctic

\begin{abstract}
A B S T R A C T
Continuous paleoenvironmental records covering the period prior to the Last Glacial Maximum in northeastern Beringia are sparse. This study presents a multi-proxy analysis of a 35-m-high yedoma exposure located on the right bank of the Itkillik River in Alaska. The exposure accumulated over 39 thousand years (kyr) during the Middle Wisconsinan Interstadial and the Late Wisconsinan glacial advance. We identified five stratigraphic units based on pollen, carbon and ice content, and isotopic composition $\left(\delta^{18} \mathrm{O}\right)$ of the sediments. Middle Wisconsinan climate in northern Alaska promoted peat accumulation prior to $33.6 \mathrm{cal}$ kyr BP (calibrated kyr before present). Reconstructed July air temperatures were $1-2{ }^{\circ} \mathrm{C}$ lower than current at $34.8 \mathrm{cal} \mathrm{kyr} \mathrm{BP}$, consistent with the timing of the interstadial climatic optimum in interior Alaska and Yukon. Colder (by up to $4{ }^{\circ} \mathrm{C}$ ) and drier conditions characterize the transition from interstadial to glacial conditions between 33.6 and 29.8 cal kyr BP. Late Wisconsinan (29.8-17.9 cal kyr BP) July air temperatures were $2-3{ }^{\circ} \mathrm{C}$ lower than today, with grassland vegetation dominated by Poaceae, Artemisia and forbs, in contrast to the modern Cyperaceae dominance. Moister and warmer environmental conditions after 17.9 cal kyr BP correspond to the Late Glacial to Early Holocene interval.
\end{abstract} (c) 2017 Elsevier B.V. All rights reserved.

\section{Introduction}

Beringia is the high-latitude region extending from the Taymyr Peninsula in eastern Russia to the Mackenzie River in Canada that remained largely unglaciated throughout the Late Pleistocene glaciations (130 to 11.7 thousand years before present (kyr BP)) (Elias and BrighamGrette, 2006).

During the Wisconsinan glaciation (71-11.7 kyr BP), Beringia was occupied by a now extinct biome formerly known as steppe-tundra (Yurtsev, 1982) or mammoth steppe (Guthrie, 1990). The plant assemblages and the amplitude of climate changes are thought to have been very heterogeneous across Beringia over the Wisconsinan (Anderson and Lozhkin, 2001), but graminoid and forb tundra growing under colder and drier climate than today seem to have dominated the Late

\footnotetext{
* Corresponding author at: Université de Montréal, Department of Geography, 520 Ch.Cote Ste-Catherine, H3C 3J7 Montréal, QC, Canada.

E-mail addresses: lyna.lapointe.el.mrabti@umontreal.ca (L. Lapointe E.), j.talbot@umontreal.ca (J. Talbot), daniel.fortier@umontreal.ca (D. Fortier), frechette.bianca@uqam.ca (B. Fréchette), jens.strauss@awi.de (J. Strauss), mkanevskiy@alaska.edu (M. Kanevskiy),yshur@alaska.edu (Y. Shur).
}

Glacial Maximum (LGM; 26.5-19.0 kyr BP) landscape (Bigelow et al., 2003).

Most of the eastern Beringia vegetation reconstructions based on pollen analysis were undertaken south of the Brooks Range from the end of the 1980s to the mid-1990s (e.g. Anderson, 1985, 1988; Anderson et al., 1988; Anderson and Brubaker, 1994). Overall, the pollen assemblages corresponding to the cold and dry late Pleistocene conditions in the lowlands of Beringia are dominated by Poaceae (Swanson, 2006). Recent macrofossil and DNA analyses have indicated that there might have been a higher proportion of forbs than was previously thought based on pollen analysis, which tends to underestimate actual vegetation diversity by over-representing high pollen-producers such as the herbs from the Poaceae, Cyperaceae and Artemisia genera (Willerslev et al., 2014).

A lot of uncertainty remains about climate and ecological changes over the Middle Wisconsinan Interstadial and the following Late Wisconsinan glacial advance. During the Middle Wisconsinan interstadial (57-29 kyr BP), part of western Beringia experienced temperatures that rose to nearly modern levels, thus allowing the treeline to migrate northward, and into mountain ranges, to approximately its modern limit. In contrast, this pattern is not observed in eastern Beringia 
(Anderson, 1985; Anderson and Lozhkin, 2001). The transition from Middle Wisconsinan to Late Wisconsinan is imprecisely dated in eastern Beringia, but floral and faunal data indicate that conditions changed from interstadial to glacial by about $29 \mathrm{kyr}$ BP (Hamilton and Fulton, 1994; Anderson and Lozhkin, 2001). July air temperatures decrease during the LGM seems to have been more substantial in eastern Beringia compared to western Beringia, as fossil beetle evidence from Siberia indicates that regional LGM summer temperatures have been close to modern levels (Alfimov and Berman, 2001).

Recently, an increasing number of multiproxy studies of yedoma sediments have contributed to a better understanding of the paleoecology of Beringia (Wetterich et al., 2008; Kienast et al., 2011; Wetterich et al., 2014). Yedoma is defined as ice- and organic rich syngenetic permafrost that is composed of an active silt deposition from a regional source and accumulation of ground ice under cold and arid conditions during the Wisconsinan (Kanevskiy et al., 2011; Strauss et al., 2012a; Schirrmeister et al., 2013; Murton et al., 2015; Strauss et al., in press). Yedoma contains well-preserved biotic remains and ground-ice features that can be used to reconstruct ecological changes and climate dynamics during the glacial, interglacial and interstadial episodes of northern high latitudes (e.g. Kaplina, 1981, 1986; Guthrie, 1990; Muhs and Bettis, 2003; Shapiro and Cooper, 2003; Sher et al., 2005; Wetterich et al., 2008; Froese et al., 2009; Strauss et al., in press). Most yedoma-based reconstructions have been undertaken at sites located in northeastern Siberia (e.g. Schirrmeister et al., 2002, 2013; Andreev et al., 2002, 2004; Murton et al., 2015), Interior Alaska (e.g. Matthews, 1974; Hamilton et al., 1988; Begét, 1990; McDowell and Edwards, 2001; Schirrmeister et al., 2016), and in the Klondike region in Yukon (e.g. Sanborn et al., 2006; Froese et al., 2009).

To date, few paleoecological studies have been conducted north of the Brooks Range in Alaska and the timing of climate changes and the ecological response of the former tundra-steppe biome to the climate fluctuations during Middle to Late Wisconsinan are poorly known. In this study, we present paleoenvironmental records from the Itkillik yedoma exposure located in northern Alaska. The primary goal is to define environmental responses related to climate changes from the Middle Wisconsinan Interstadial to the Holocene. Our objectives are to (1) reconstruct the regional vegetation using pollen analysis; (2) infer mean July air temperature $\left({ }^{\circ} \mathrm{C}\right)$, seasonal air temperature contrast $\left(\mathrm{T}^{\circ} \mathrm{C}\right.$ July $-\mathrm{T}^{\circ} \mathrm{C}$ January), and July sunshine values (expressed in \% of hours of bright sunshine between sunrise and sunset) using a pollen-based modern analog technique (MAT); and (3) establish links between the climate information derived from sediment and ground-ice records (geochemistry, isotopes, volumetric ice content) and the pollen-based reconstructed climate.

\section{Study area}

The Itkillik yedoma exposure $\left(69^{\circ} 34^{\prime} 0.72^{\prime \prime} \mathrm{N}, 150^{\circ} 52^{\prime} 7.73^{\prime \prime} \mathrm{W}\right)$ is located in the continuous permafrost zone, at the boundary between the Arctic Coastal Plain and the Arctic Foothills in northern Alaska (Fig. 1a). According to the Anaktuvuk River meteorological station (altitude: $81 \mathrm{~m} ; 69^{\circ} 27^{\prime} \mathrm{N}, 151^{\circ} 10^{\prime} \mathrm{W}$ ), the climate is characterized by severe winters with January air temperatures of $-29.1{ }^{\circ} \mathrm{C}$ and short summers with July temperatures of $13.0^{\circ} \mathrm{C}$. The mean annual air temperature is $-10.2{ }^{\circ} \mathrm{C}$ and the annual total precipitation is $122 \mathrm{~mm}$, with 82 to $107 \mathrm{~mm}$ (67 to 88\%) falling as snow (Kane et al., 2014). The ground surface is slightly undulating and underlain by a poorly drained, silty mineral sediment with a shallow organic surface layer (Viereck et al., 1992). Cyperaceae species such as Eriophorum vaginatum and Carex bigelowii are the primary tussock formers, while shrubs are sparse (Boggs et al., 2012). Previous studies in this area have been undertaken to assess the extent of loess-like sediments in the region (Carter, 1988), permafrost characteristics (Carter, 1988; Kanevskiy et al., 2011; Strauss et al., 2012a; Murton et al., 2015), and the rates and patterns of riverbank erosion (Kanevskiy et al., 2016).
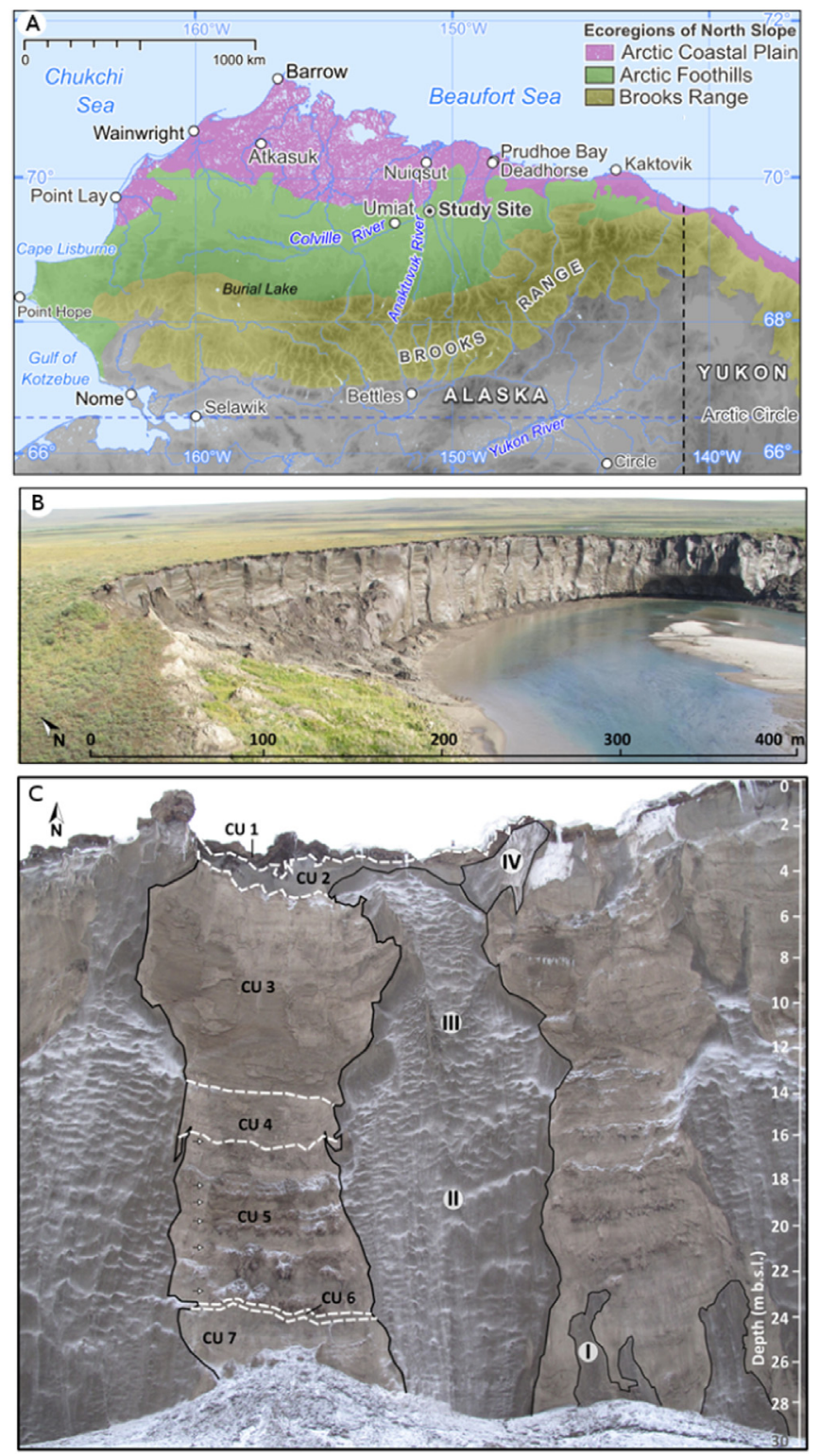

Fig. 1. Study site. A) Location map of the study site at the Arctic Coastal plain and Arctic Foothills border (USGS, 2001); B) Photograph of the exposed bluff (photograph by Mikhail Kanevskiy, July 2007); C) Photograph of the vertical cross section studied with cryostratigraphic units (CU1-7) and stages of aggradation of ice-wedges (I-IV) Kanevskiy et al. (2011), and buried peat layers identified with arrows (photograph by Jens Strauss, May 2012).

The studied sequence is a vertical bluff exposed since the mid-1990s by thermo-erosional processes caused by the meandering of the Itkillik River (Kanevskiy et al., 2016). The surface elevation ( $~ 85 \mathrm{~m}$ above sea level) ranges from 30 to $35 \mathrm{~m}$ above the local river level and the total length of the exposed face exceeds $680 \mathrm{~m}$ (Fig. 1b). The cliff face reveals undisturbed sections of late Pleistocene syngenetic permafrost that formed during the Middle and Late Wisconsinan. Based on data from field work conducted in 2007, seven cryostratigraphic units (CU1-CU7 in Fig. 1c, Supplementary Table 1) are present within the exposed yedoma face (Kanevskiy et al., 2011). Three stages of ice-wedge aggradation are recognized at the site (Strauss et al., 2012b). The silty sediments contain sparse organic material including rootlets and wood and six peat layers were visually identified between 26 and $16 \mathrm{~m}$ below surface level (b.s.l.), based on their colour, continuity and the presence of visible organic remnants (Strauss et al., 2012b) (Fig. 1c). The cliff is currently eroding at a rate of $\sim 20 \mathrm{~m} \mathrm{year}^{-1}$ (Kanevskiy et al., 2016). 


\section{Methods}

\subsection{Sampling}

A sediment column in the central part of the exposure was sampled by rappelling from the top of the cliff in May 2012. An overhang between 20.5 and $9.7 \mathrm{~m}$ b.s.l. was impossible to reach. Samples with the same stratigraphic position were extracted from adjacent sediment columns to fill the gap. Surfaces were first cleaned with a hammer, a pic or an axe, and then a hand-held core-drill with a $4.7 \mathrm{~cm}$ diameter hole saw was used to extract 45 sediment samples and 48 samples from an adjacent ice wedge. The drilling head was cleaned between each sample extraction. Samples were cleaned of the drilling mud and kept frozen during fieldwork and transport to laboratory. Subsamples from the same depths were used for biogeochemistry, ice content analysis, geochronology, and pollen extraction (Strauss et al., 2012b). The biogeochemistry data and 10 radiocarbon dates from Kanevskiy et al. (2011) obtained from boreholes drilled in 2007 were also used to increase the sampling resolution. Although the locations of the 2012 sampling sites were located approximately $100 \mathrm{~m}$ away from the 2007 sites due to riverbank erosion, no differences in cryostratigraphy were detected between the sampling locations of these two field campaigns. The general location of the peat layers was similar between the two field campaigns, as well as the organic $C$ patterns, confirming that the general stratigraphy was similar between the two sampling locations.

\subsection{Biogeochemistry}

To quantify and determine the nature of carbon in the sediments, total carbon (TC) and total organic carbon (TOC) were measured. 45 intact samples of $\sim 50 \mathrm{~cm}^{3}$ (including coarse organic material present in the sediment matrix) were freeze-dried (sublimator 3-4-5, Zirbus Technology) and homogenized by grinding (Pulverisette 5 planetary mill, Fritsch) before being measured by a carbon analyzer (Vario EL III, Elementar). Two $5 \mathrm{mg}$ sub-samples per sample were taken and encapsulated in two zinc capsules. To ensure complete oxidation of the sample during measurements $\sim 10 \mathrm{mg}$ of tungsten-(VI)-oxide were added. Background signals were detected by measuring a blank capsule at the beginning and calibration standards after each 20 samples. The quantified measurement accuracy is $<0.1 \mathrm{wt} \%$. Total organic carbon content was measured with a TOC analyzer (Vario Max C, Elementar). Four calibration standards were measured after each 14 samples. The measurement accuracy is $<0.1 \mathrm{wt} \%$.

As isotopic values can be used as a paleoclimate proxy, $\delta^{18} \mathrm{O}$ from 45 samples obtained from the ice wedge (Fig. 1c; central ice wedge) were analyzed based on mass spectrometric detection of isotopes (Hoefs, 2008). For this purpose a Finnigan MAT Delta-S mass spectrometer was combined with two equilibration units (MS Analysetechnik, Berlin). Before measuring a sequence of water samples, the laboratory reference standard NGT1 (snow from the North Greenland Traverse) was used as reference material. Additionally, for quality control, standards of different isotopic composition were employed for each equilibration unit. Standard deviations were generally better than $0.1 \%$. The detected values of $\delta^{18} \mathrm{O}$ were further recalculated to the Vienna Standard Mean Ocean Water (VSMOW) standard with the software ISODAT®.

\subsection{Ice content}

The characteristics of the ice are indicative of the climatic conditions prevailing during the aggradation. To calculate the volumetric ice content of sediments, we weighed 48 frozen samples using a balance ( $0.1 \mathrm{~g}$ accuracy, Kern FCB 8 K0.1) and determined their volume by water displacement. To verify these volumetric measurements, we calculated the volume of the dry sample and the volume of the wet sample by assuming an ice density of $0.9167 \mathrm{~g} \mathrm{~cm}-3$ and a solids density of $2.65 \mathrm{~g} \mathrm{~cm}-3$ (adapted from Strauss et al., 2012a).

\subsection{Age-depth model}

The plant material or bulk peat from 20 samples was isolated for radiocarbon dating (Table 1 ). Whenever available, we chose plant aerial macro remains over bulk peat or unidentifiable remains to avoid introducing variability in the dating (e.g. Nelson et al., 1988). When this was not possible, unidentified plant remains likely composed of rootlets and aerial components were dated. Radiocarbon dates were calibrated using IntCal13 for terrestrial northern hemisphere material (Reimer et al., 2013). Six infinite ages were excluded from the age-depth model produced by the R Bacon package (Blaauw and Christen, 2011). The Bacon model divides a core into many thin vertical sections using a Bayesian approach and then, through millions of Markov Chain Monte Carlo (MCMC) iterations, an age-depth model is built based on the accumulation rate for each of these sections (Blaauw and Christen, 2011). Ages are reported as the mean of each iteration for a $1 \mathrm{~cm}$ increment with the minimum and maximum of $1 \sigma$. Period chronology is presented as rounded cal. kyr BP, omitting the uncertainty estimate for clarity.

\subsection{Pollen}

Pollen extraction using heavy-liquid separation was performed on 19 samples obtained from the main sampling profile and 7 samples from nearby sub-profiles. The treatment involved acid digestion of carbonate with hydrochloric acid $(\mathrm{HCl})$, organic matter deflocculating with potassium hydroxide ( $\mathrm{KOH})$, sieving (15 and $250 \mu \mathrm{m})$, heavy liquid density separation using sodium polytungstate (SPT) and acetolysis. Eucalyptus globulus exotic markers suspensions (Greer laboratory) were added in order to quantify pollen concentrations. Pollen samples were mounted in glycerin and analyzed under light microscope (Leitz, Wetzlar, D-69301) at $400 \times$ magnification. When concentrations were over 1500 grains $\mathrm{cc}^{-1}$ at least 300 terrestrial pollen grains were counted, otherwise 150 pollen grains were counted. Pollen diagram was graphed using the C2 software (Juggins, 2007). All identified pollen grains of trees, shrubs and herbs were used to calculate the pollen sum. Determination of pollen units was done using a temporally constrained incremental sum of squares cluster analysis (CONISS; Grimm, 1987). For CONISS, the relative frequencies (in percent) of the pollen taxa were square-root transformed. Other palynomorphs such as algae and spores (undifferentiated) were not included in the calculation of pollen concentrations or for the CONISS dendrogram.

\subsection{Climate reconstruction}

Climate was reconstructed using the modern analogue technique (MAT, e.g. Guiot, 1990) and the North American and Greenland Modern Pollen Database (Whitmore et al., 2005). The database contains 57 taxa of tree, shrubs and grass. Each of the identified taxa at the Itkillik site was present in the database.

Modern pollen samples from the western boreal subarctic and arctic biomes north of $50^{\circ} \mathrm{N}$ and west of $100^{\circ} \mathrm{W}$ were considered as potential modern analogues candidates ( $n=981$ modern pollen assemblages). The five closest analogs were used to compute the reconstructed climate variables. The accuracy of reconstruction can be assessed from the slope and the coefficient of multiple determination $\left(\mathrm{R}^{2}\right)$, as well as from the standard deviation of the difference between inferred and observed values that corresponds to the root mean square error (RMSE) (e.g. Sawada et al., 2004). July air temperatures were reconstructed $\left(\mathrm{R}^{2}=0.84\right.$; $\left.\mathrm{RSME}=1.4{ }^{\circ} \mathrm{C}\right)$ to allow a comparison with available beetle-based regional paleo-climate reconstructions (Elias, 2001; Kurek et al., 2009). Seasonal air temperature contrast $\left(\mathrm{R}^{2}=0.82 ; \mathrm{RSME}=3.1\right.$ $\left.{ }^{\circ} \mathrm{C}\right)$ and July sunshine values $\left(\mathrm{R}^{2}=0.85\right.$; $\left.\mathrm{RSME}=3.0 \%\right)$ were selected for the reconstruction as they also have good $\mathrm{R}^{2}$ and RSME values (See Supplementary Fig. 1). Current climate estimates were obtained by calculating the average values from the nearby modern analogs and the 
Table 1

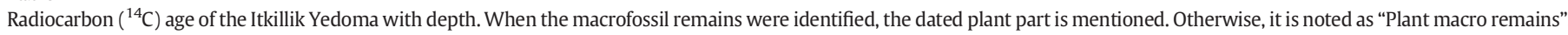

\begin{tabular}{|c|c|c|c|c|c|}
\hline Depth (m) & Age ${ }^{14} \mathrm{C}$ yr BP & Age cal kyr BP & Laboratory number & Material & Source \\
\hline 0.7 & $5320 \pm 35$ & $6100 \pm 107$ & OS-66781 & in situ peat & Kanevskiy et al., 2011 \\
\hline 1.3 & $8610 \pm 35$ & $9594 \pm 68$ & OS-66782 & in situ peat & Kanevskiy et al., 2011 \\
\hline 2.3 & $14,370 \pm 100$ & $17,510 \pm 312$ & Poz-51,789 & Plant macro remains & This study \\
\hline 3.0 & $14,300 \pm 50$ & $17,408 \pm 196$ & OS-66783 & Twigs & Kanevskiy et al., 2011 \\
\hline 4.0 & $16,550 \pm 75$ & $19,949 \pm 245$ & OS-66784 & Twigs & Kanevskiy et al., 2011 \\
\hline 5.4 & $19,950 \pm 180$ & $23,999 \pm 429$ & Poz-51,791 & Plant macro remains & This study \\
\hline 9.3 & $24,290 \pm 190$ & $28,312 \pm 408$ & Poz-51,795 & Plant macro remains & This study \\
\hline 11.0 & $29,300 \pm 200$ & $33,466 \pm 437$ & OS-66785 & Twigs & Kanevskiy et al., 2011 \\
\hline 13.7 & $25,450 \pm 280$ & $29,642 \pm 744$ & Poz-51,797 & Plant macro remains & This study \\
\hline 15.0 & $26,300 \pm 130$ & $30,609 \pm 309$ & OS-66786 & Twigs & Kanevskiy et al., 2011 \\
\hline 16.0 & $23,900 \pm 110$ & $27,966 \pm 262$ & OS-66780 & Twigs & Kanevskiy et al., 2011 \\
\hline 19.5 & $28,330 \pm 390$ & $32,357 \pm 965$ & Poz-51,796 & Plant macro remains & This study \\
\hline 20.6 & $43,500 \pm 1700$ & $47,403 \pm 2506$ & Poz-51,788 & in situ peat & This study \\
\hline 23.0 & $41,700 \pm 460$ & $45,137 \pm 777$ & OS-66787 & Fine-grained organic matter & Kanevskiy et al., 2011 \\
\hline 23.8 & $>45,000$ & Infinite & Poz-51,793 & Plant macro remains & This study \\
\hline 25.9 & $>45,000$ & Infinite & Poz-51,794 & Plant macro remains & This study \\
\hline 27.5 & $>46,000$ & Infinite & Poz-51,792 & Plant macro remains & This study \\
\hline 28.9 & $>48,000$ & Infinite & Poz-51,798 & Plant macro remains & This study \\
\hline 30.9 & $>48,000$ & Infinite & OS-66777 & in situ peat & Kanevskiy et al., 2011 \\
\hline 31.8 & $>47,500$ & Infinite & OS-66778. & Fine-grained organic matter & Kanevskiy et al., 2011 \\
\hline
\end{tabular}

Anaktuvuk River station (July air temperature: $9{ }^{\circ} \mathrm{C}$; Seasonal air temperature contrast: $35.5^{\circ} \mathrm{C}$; July sunshine: $39.6 \%$ ).

Similarity between fossil and modern pollen assemblages was assessed using the squared chord distance (SCD) (Overpeck et al., 1985). Values of SCD vary between zero and two, with higher values indicating greater dissimilarity. The adopted threshold for the analog is 0.21 , which is in agreement with suggested values for MAT-based reconstructions from fossil pollen assemblages in the Arctic biome in Fréchette et al. (2008). SCD threshold values over 0.20 for the Arctic biome reduces the probability of generating false-negative errors, such as the omission of contrasting pollen assemblages originating from sites experiencing similar climate and therefore representing viable analogues (Fréchette et al., 2008). Climate reconstructions were performed with the Bioindic package (Guiot and Gally, 2014) built on the $\mathrm{R}$ platform. More details on the MAT approach used here are given in Fréchette et al. (2008).

\section{Results}

\subsection{Sediment and ground-ice records}

Sedimentary and biogeochemical characteristics of the sediments were grouped into five units based on pollen and climate reconstructions for consistency (U1-5) (Fig. 2, see Section 4.3 and 4.4). Overall, TC shows an average of $4.9 \mathrm{wt} \%$ and is mostly inorganic (generally over $75 \%$ of TC), while the volumetric ice content including segregated and pore ice averages $62 \%$.

Sediments in the first unit (U1: 30.0-25.3 m b.s.l.) are composed of yellowish-grey silt. The U1 TC values are as low as $2.7-4.7 \mathrm{wt} \%$ with an average of $0.4 \mathrm{wt} \%$ as organic compounds. The volumetric ice content of sediments between ice-wedges varies from 48.5 to 65.9 vol\%. Stable isotope analysis shows an average $\delta^{18} \mathrm{O}$ value of $-33.6 \%$. Isotopic anomaly decreases slightly towards the top of the unit.

Sediments in the second unit (U2: 25.3-20.9-m) are composed of organic-rich silt with medium grained sand that grades upwards into silty peat with graminoid remains. TC values increase in U2, varying between 4.0 and $29.4 \mathrm{wt} \%$ with a TOC average of $4.5 \mathrm{wt} \%$. Systematic differences in TOC values between the two sampling campaigns may be due to the differences in TOC measurement methods. However, in both cases, TOC enrichment matches with the position of peat layers located in this unit and U3 (23.4-24.2, 21.5-22.7, 19-19.8, 17-17.6, 16.0 m b.s.l.). At $22.5 \mathrm{~m}$ b.s.l., TC reaches $29.4 \mathrm{wt} \%$, while the TOC reaches $31.4 \mathrm{wt} \%$ making $\mathrm{U} 2$ the most organic rich unit. Volumetric ice content of segregated ice increases upwards and reaches values as high as $82.5 \mathrm{vol} \%$. The peak in ice content at $23.3 \mathrm{~m}$ b.s.l. corresponds to an ancient position of the ice-rich upper horizon of permafrost, known as the intermediate layer (Shur, 1988; Shur et al., 2011). $\delta^{18}$ O decreased to average values of -28.7 with lower values (until U5) concordant to $23.3 \mathrm{~m}$ b.s.l.

Sediments in the third unit (U3: 20.9-13.3 m b.s.l.) are composed of yellow-grey silt with inclusions of organic material, rootlets and twigs. The TC value of U3 varies from 10.4 to $3.6 \mathrm{wt} \%$ (average TOC of $1.9 \mathrm{wt} \%$ ) and tends to slightly decrease upwards. Highest TOC values

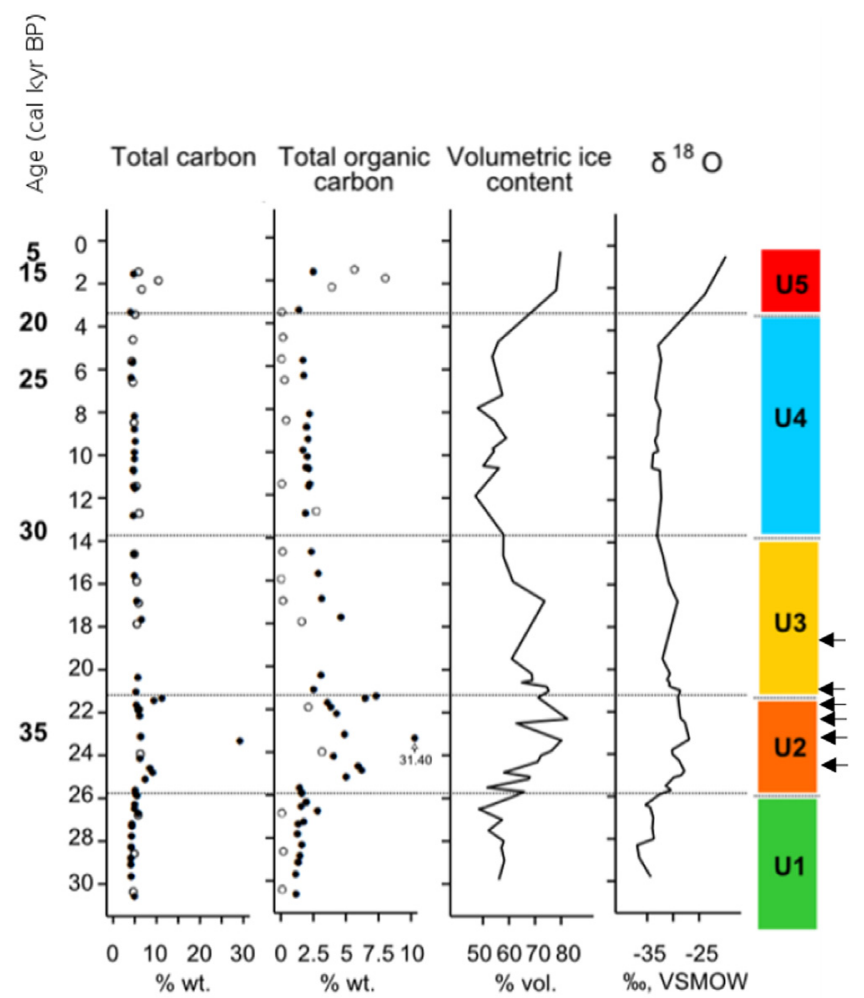

Fig. 2. Biogeochemical, ice content, and $\delta^{18} \mathrm{O}$ data from the Itkillik Yedoma exposure over $\sim 39 \mathrm{kyr}$. Total carbon and total organic carbon are represented in weight percent (wt\%); volumetric ice content values are represented in volume percent (vol\%); $\delta^{18} \mathrm{O}$ anomaly values are represented in parts per thousand compared to the Vienna Standard Mean Ocean Water (\%, VSMOW). Note that data shown as empty circles are from the 2007 sampling campaign (Kanevskiy et al., 2011). Data from 2012 (this study) are illustrated as black filled circles. Units (U1 to U5) are given on the right-hand side. Peat layers are identified with the black arrows. 
correspond to the location of the uppermost peat layer ( $16 \mathrm{~m}$ b.s.l.). As volumetric ice content decreases by about 17.4 vol\% (from 73.8 to $56.5 \mathrm{vol} \%$ ) over the unit, stable isotope values for wedge ice become more stable with an average value of $-30.9 \%$ or $\delta^{18} \mathrm{O}$.

Sediments in the fourth unit (U4: 13.3-3.3 m b.s.l.) are yellow-grey silts with small in situ inclusions of poorly decomposed rootlets and twigs. The U4 TC values vary between 3.0 and $4.9 \mathrm{wt} \%$, while TOC is low (average of $0.6 \mathrm{wt} \%$ ). Volumetric ice contents are lower, with values varying between 47.1 and $59.0 \mathrm{vol} \%$. The $\delta^{18} \mathrm{O}$ values are very different from modern values, with an average of $-33.0 \%$.

In the last unit (U5: 3.3-0 m), organic-rich silt with some clay and very fine sand with peat and moss become dominant at the surface. This unit shows a net increase in TOC reaching 8.18 wt\% (average of $2.45 \mathrm{wt} \%)$. TC remains elevated at the bottom of this unit and reaches about $17.2 \mathrm{wt} \%$ near the surface. Volumetric ice content exceeds $75 \mathrm{vol} \%$ (78.9\% average) indicating the position of the modern intermediate layer (Shur, 1988; Shur et al., 2011; French and Shur, 2010). Stable isotope analysis shows rapidly decreasing values going upward the unit with $\delta^{18} \mathrm{O}$ that reaches nearly modern values.

\subsection{Geochronology}

Except for two overlapping radiocarbon dates (11 and $16 \mathrm{~m}$ b.s.l.), ages generally increase with depth (Fig. 3). Sediment accumulation varies between 0.01 and $0.33 \mathrm{~cm} \mathrm{yr}^{-1}$ with an average rate of $0.16 \mathrm{~cm} \mathrm{yr}^{1}$. The fastest vertical sediment accumulation occurred prior to $28.1 \mathrm{cal} \mathrm{kyr} \mathrm{BP}$ with average rates over $0.17 \mathrm{~cm} \mathrm{yr}^{-1}$. From 31.7 to 30.7 cal kyr BP and from 29.9 to 28.4 cal kyr BP average accumulation rates reached about $0.25 \mathrm{~cm} \mathrm{yr}^{-1}$. Slower accumulation rates were recorded from 28.4 to 17.8 cal kyr BP (average rates are below $0.10 \mathrm{~cm} \mathrm{yr}^{-1}$ ) and especially after $17.1 \mathrm{cal} \mathrm{kyr}$ BP (average rates of $0.01 \mathrm{~cm} \mathrm{yr}^{-1}$ ). It should be noted that the landscape-scale sedimentation rates were much slower due to the presence of ice wedges. Landscape-scale rates of accumulation cannot be calculated based on our data.

\subsection{Pollen}

Based on the CONISS cluster analysis, the pollen diagram was subdivided into five units (U1-5) corresponding to changes in taxa composition and abundance (Fig. 4). The profile is dominated by herbaceous taxa, notably Poaceae and Cyperaceae. Pollen grains of boreal trees such as Picea and Pinus are from distal sources as they are not currently present at the study site, and were very likely not present during the Middle and Late Wisconsinan period.

U1 (30.0-25.3 m b.s.l., > 34.8 cal kyr BP) is characterized by a low pollen concentration $\left(<2500\right.$ pollen grains $\left.\mathrm{cc}^{-1}\right)$. We observed pollen grains of Poaceae ( $>50 \%)$, Cyperaceae ( 9-23\%), and to a lesser extent, of Artemisia, Tubuliflorae (sub-family of Asteraceae), and Brassicaceae. Picea and Pinus reach their highest values of the entire sequence $(\sim 10 \%)$.

U2 (25.3-20.9-m b.s.l., > 34.8-33.6 cal kyr BP) shows a 44\% increase in Cyperaceae pollen grains concentration (from 28 to $72 \%$ ), while Poaceae decreases by $47 \%$ (from 65 to $18 \%$ ). Other minor herbs and forbs are less represented than in the first unit. Zygnema algae occurrence is high and reaches an abundance peak of 20\% at 35 cal kyr BP. The percentage of boreal tree taxa (Picea, Pinus) substantially decreases to $<2 \%$ from the previous unit. An upward increase of total pollen concentration was observed over this unit, with a maximum value reaching $\sim 5000$ grains $\mathrm{Cc}^{-1}$.

U3 (20.9-13.3 m b.s.l., 33.6-29.8 cal kyr BP) is notable for having high Cyperaceae abundance at the bottom of the unit. It decreases upward by $42 \%$ (from 94 to 52\%). Inversely, Poaceae increased by $10 \%$ (from 2 to $12 \%$ ) concurrently with arboreal pollen (from 1 to 9\%) over this unit. Minor herbs and forbs abundance and diversity are lower than before, but tend to increase at the end of the unit. Total pollen concentration slightly decreases compared to U2 to about 3400 grains $\mathrm{cc}^{-1}$.

U4 (13.3-3.3 m b.s.l., 29.8-17.9 cal kyr BP) shows a clear dominance of Poaceae over Cyperaceae. This last taxon tends to increase upwards (31\% on average, going from 64 to 33\% for Poaceae and 35\%, going from 4 to 39\% for Cyperaceae). Minor herbs and forbs abundance and diversity reach their highest values, with peaks of Artemisia, Asteraceae (sub-family of Tubuliforae) and Brassicaceae. Boreal tree taxa stay abundant ( 10\%). The lowest pollen concentrations of about 2000 grains $\mathrm{Cc}^{-1}$ were measured in this unit.

The pollen assemblage of U5 (3.3-0 m b.s.l., 17.9 cal kyr BP-modern) is dominated by Cyperaceae (67-96\%), in agreement with current surface vegetation. Forbs are poorly represented and Poaceae have decreased compared to the previous unit $(<10 \%)$. Pollen concentration exceeds 2500 grains $\mathrm{cc}^{-1}$.

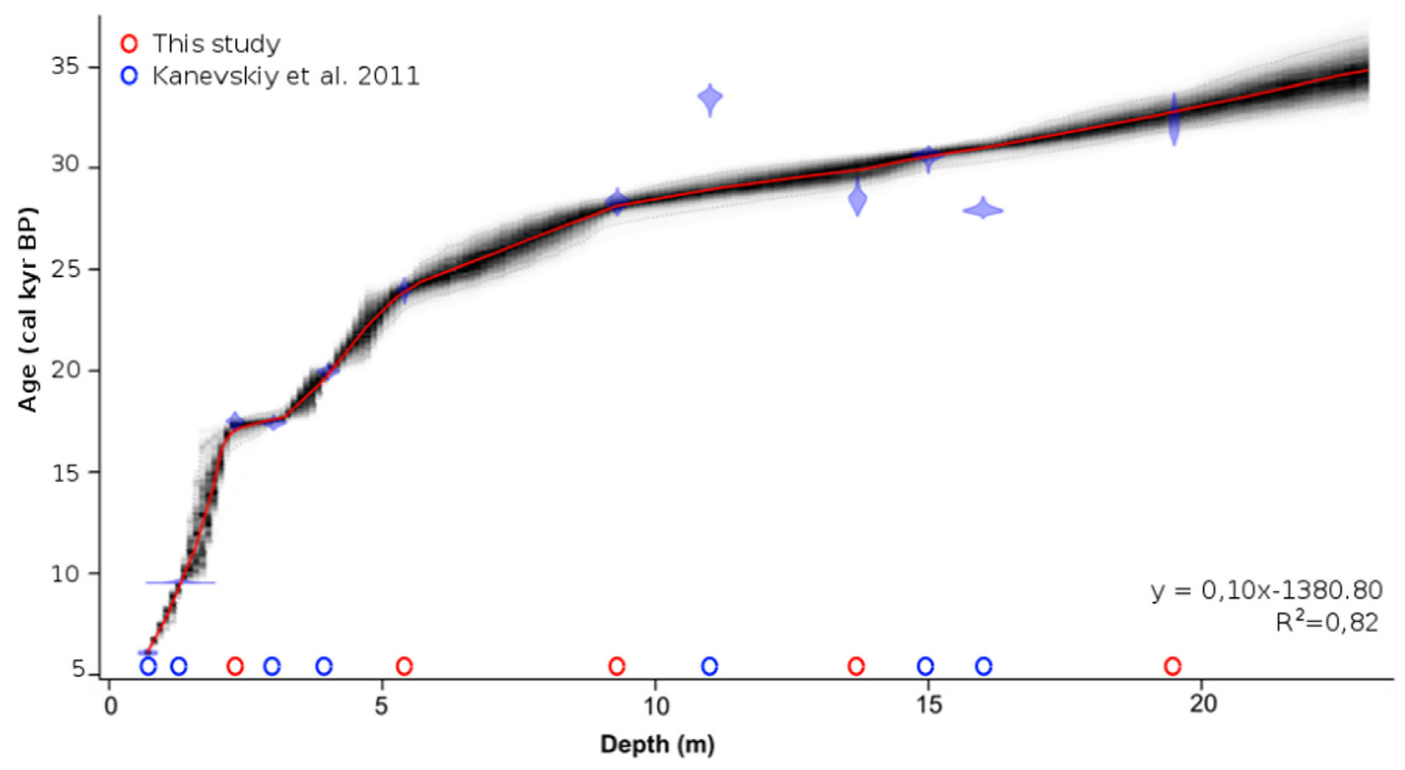



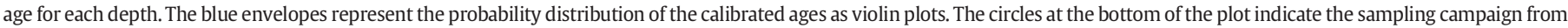

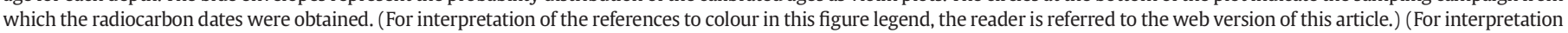
of the references to colour in this figure legend, the reader is referred to the web version of this article.) 


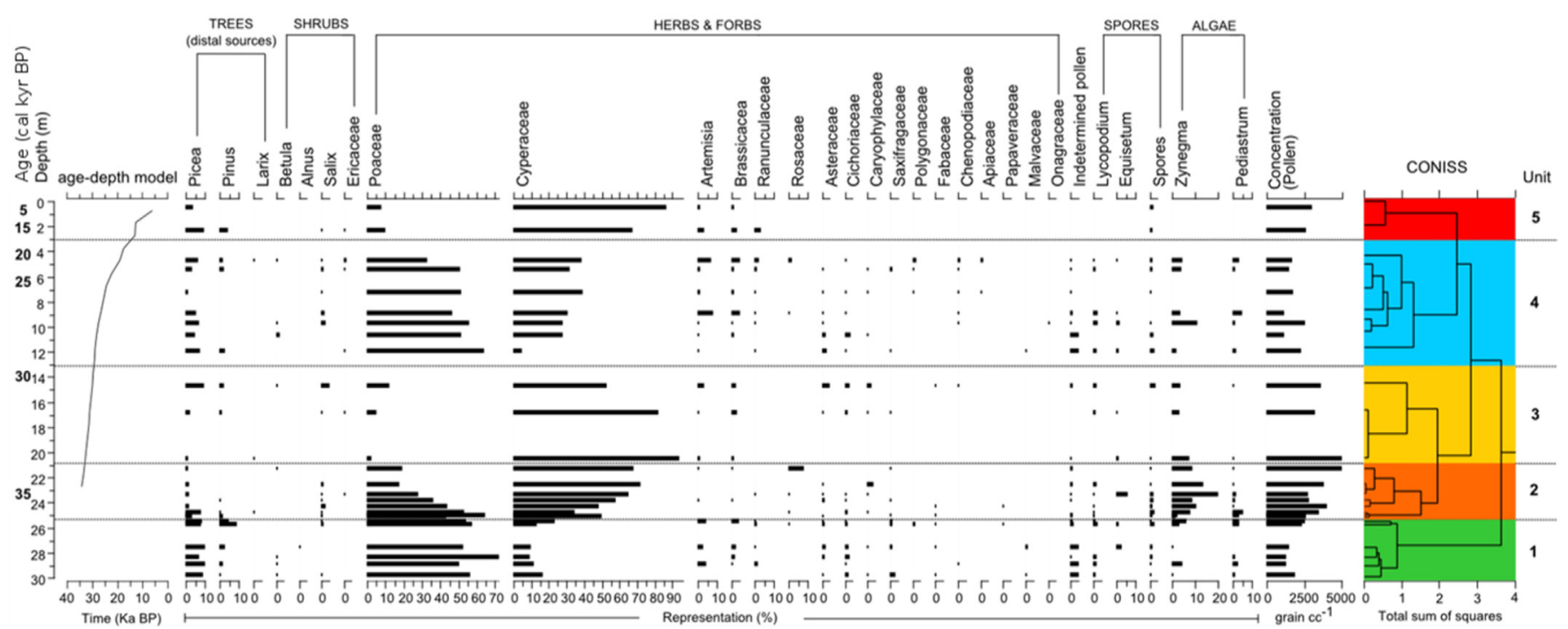

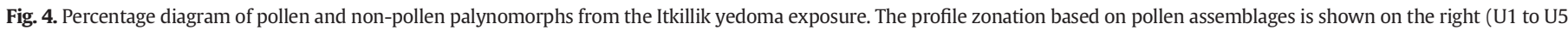
and CONISS results).

\subsection{Climate reconstruction}

Climate reconstructions based on the 26 fossil pollen assemblages are presented by unit (U1-U5, as in the previous section) and are expressed as anomalies relative to the current climate. Close analogs for fossil pollen assemblages exist in the modern database (Supplementary Fig. 2), with SCD values ranging from $0.10-0.18$ in U2, $0.12-0.14$ in U3, and $0.09-0.17$ in U5 for the best analogues. Most of the pollen assemblages from $\mathrm{U} 1$ and one from $\mathrm{U} 4$ have no modern analog with a SCD value below 0.20 (Fig. 5).
Only two out of six pollen assemblages ( $29.8 \mathrm{~m}$ b.s.l.) present in U1 have five valid modern climate analogs (presented with dashed lines in Fig. 5). July air temperatures are about $2^{\circ} \mathrm{C}$ lower than modern and seasonal air temperature contrasts are from 4 to $2{ }^{\circ} \mathrm{C}$ lower than modern going upwards of the unit. July sunshine is $1-6 \%$ higher than current.

Closer analogues were found in U2. Average SCD for the closest ana$\log$ is 0.12 and seven out of eight samples have five valid analogs. The most frequent closest analog is a modern pollen assemblage located $225 \mathrm{~km}$ north-west of the Itkillik yedoma exposure $\left(71^{\circ} 2^{\prime} \mathrm{N}, 154^{\circ} 58^{\prime}\right.$ W, Brubaker and Anderson, unpublished site). July air temperature

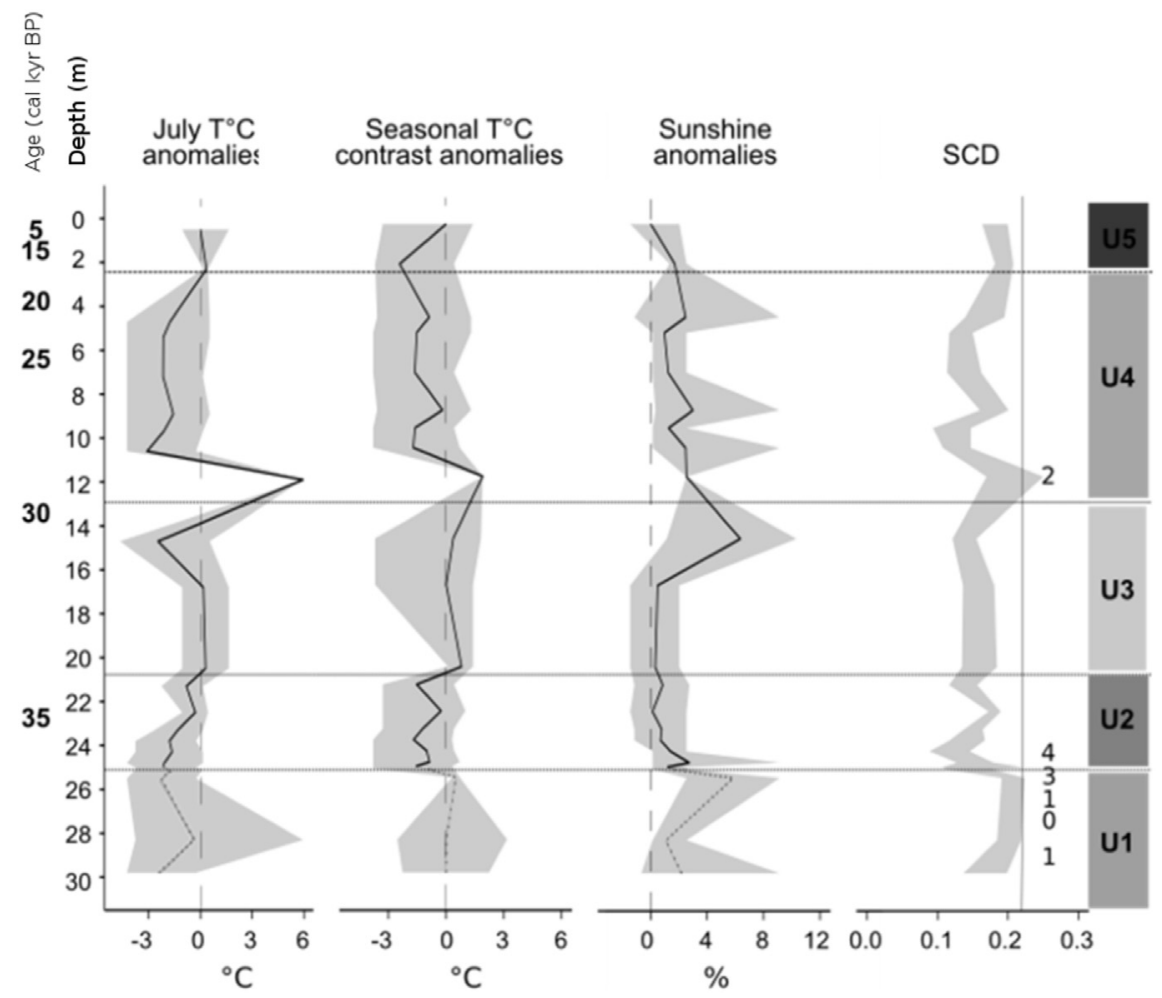

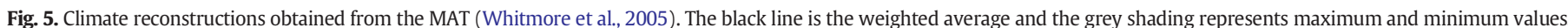

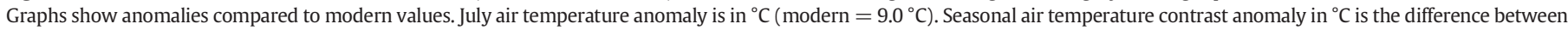

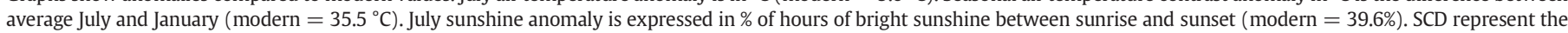
squared chord distance (threshold $=0.21$ ). Note that if less than five analogs were found, the number of analogs found is indicated on the graph showing the SCD. 
anomaly tends to decrease with time from -2 to $-1{ }^{\circ} \mathrm{C}$. Average seasonal air temperature contrast anomaly is $-1{ }^{\circ} \mathrm{C}$. July sunshine anomaly decreases to nearly modern value (from 3 to $<1 \%$ ).

For U3, the MAT found five valid analogs with an average SCD for the closest analogues of 0.13 . July air temperature is close to modern values between 33.6 and $31.4 \mathrm{cal}$ kyr BP and decreases drastically to reach an anomaly of $-2.5^{\circ} \mathrm{C}$ by $30.4 \mathrm{cal} \mathrm{kyr}$ BP. Seasonal air temperature contrast is similar to current values. July sunshine is approximately equivalent to the modern value for most of the unit. Climate reconstructions for U3 should be interpreted cautiously as they are based on only three pollen assemblages.

Six out of seven pollen assemblages for U4 have good analogs with an average SCD value of 0.12 for the closest (first) analog. However, the bottom sample of the unit (11.9 m b.s.l.; 29.3 cal kyr BP) has only one analog, indicating that its pollen assemblage is very different from modern ones. July air temperature increases slightly from 3 to $2{ }^{\circ} \mathrm{C}$ (lower value) through the unit. Seasonal air temperature contrast varies between 1 and $2{ }^{\circ} \mathrm{C}$ lower than current. July sunshine varies from 1 to $3 \%$ higher than modern values.

Paleoclimate reconstructions for U5 are based on only two pollen assemblages with a high SCD average value of 0.17 for the closest analog. MAT found five valid analogues for the two surface samples. July air temperature is close to the modern value. Seasonal air temperature contrast and July sunshine anomalies vary respectively by about $-2{ }^{\circ} \mathrm{C}$ and $-2 \%$ compared to current value over the unit.

\section{Discussion}

\subsection{Chronology of paleoenvironmental records}

Lack of chronological control in U1 and early U2 prevents us from assessing a precise age for the sediments deeper than $23.3 \mathrm{~m}$ b.s.l. (prior to 35 cal kyr BP). Extrapolation from average accumulation rates indicates that if there was no interruption in sediment deposition, $\mathrm{U} 1$ is probably no older than 39 cal kyr BP and is likely encompassed into the Middle Wisconsinan interstadial. Thus, we interpret proxy data changes over U1-3 ( 39 to 29.8 cal kyr BP) as climatic fluctuations occurring during the interstadial. However, as the assignment of U1-3 is based on an extrapolation of finite $14 \mathrm{C}$ ages and there is no evidence that sedimentation is continuous between $\mathrm{U} 1$ and $\mathrm{U} 2$, we remain very cautious about the interpretation of U1 and early U2. Radiocarbon dating on Middle Wisconsinan permafrost samples is complicated due to detection limits and cryoturbation that can relocate material (e.g. Wetterich et al., 2014). For instance, the reversed ages at 11 and $16 \mathrm{~m}$ b.s.l. (Table 1 ) could be explained by erosion and redisposition of younger sediments or cryogenic relocation processes. U4 age is related to the following Late Wisconsinan glacial advance in the surrounding areas (29.8 to 17.9 cal kyr BP), while U5 corresponds to the Late Glacial transition into the Holocene $(<17.9$ cal kyr BP) (Fig. 6). Considering the limited age control, we also remain cautious about the chronology of U5.

The chronology of sediment accumulation rate fluctuations coincides roughly with sediment unit boundaries. Therefore, we interpret rapid accumulation rates as active Pleistocene sedimentation processes and the subsequent slow-down observed about 17.9 cal kyr BP as the transition to Holocene, characterized by more active organic accumulation and less active deposition of loess.

\subsection{Beringian palaeoenvironments}

As yedoma form by long distance deposition of eolian sediments, the pollen found at the Itkillik site is interpreted as being representative of regional vegetation and climate. Compared to many Beringian diagrams, pollen assemblages from the Itkillik yedoma are poorly diversified with only 14 minor taxa (Fig. 4). The most important patterns observed across the units are the shifts between Cyperaceae and Poaceae dominance in pollen assemblages. Thus, it is possible that shifts in grass and sedges are almost exclusively driving the reconstructed changes in regional climate. When Cyperaceae dominated the pollen assemblages (U2, U3 and U5), ice and organic carbon contents are higher locally at the site. Isotopic values were also more similar to modern values of snow, implying warmer and moister conditions that where favorable to peat aggradation. Inversely, when Poaceae and other minor taxa percentage are higher, other proxies indicate drier, windier, and colder conditions that are promoting silt accumulation.

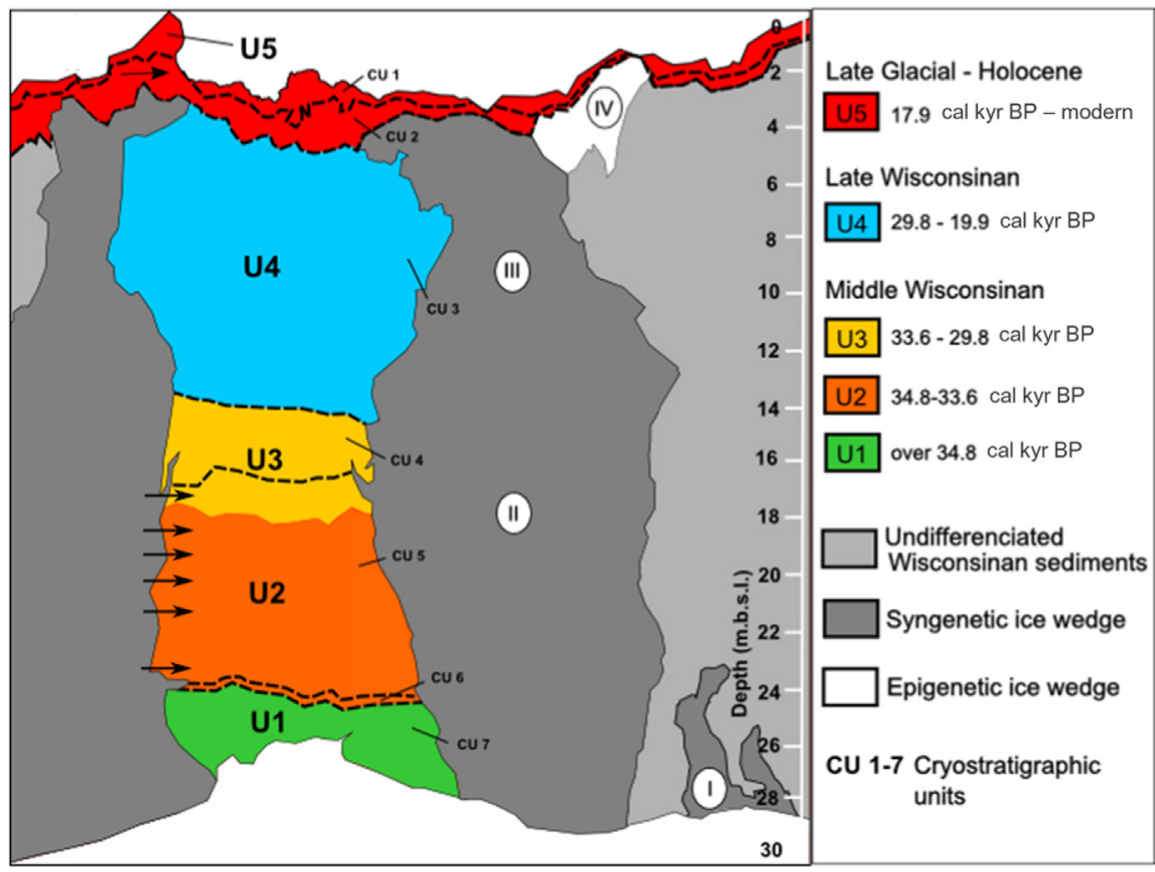

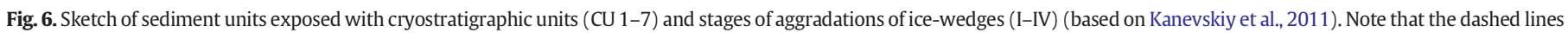
represent the boundary between CU and that the black arrows indicate the locations of the peat layers. 


\subsection{Unit 1}

Presence of Poaceae and Artemisia, and a high diversity of forbs taxa in U1, which we interpret as approximately covering the $\sim 39$ 36 cal kyr BP interval, suggest that dry conditions prevailed in a grass environment (Zazula, 2002). Reconstructed July air temperatures indicate colder than modern climate conditions during that time interval. The poor analog quality found for $\mathrm{U} 1$ is interpreted as conflicting pollen rain inputs from contrasted vegetation across eastern Beringia. Considering the chronological uncertainties, we must remain cautious about the interpretation of reconstructed climate for U1. The low organic carbon content is indicative of cold conditions that do not favor carbon accumulation. The lower $\delta^{18} \mathrm{O}$ values reported in U1 compared to modern snow values of $-22.3 \%$ reported for northern Alaska (Sloat, 2013) and to modern ice-wedges $(-25,0 \%, n=3)$ sampled at the Itkillik River site is also indicative of colder than modern conditions. The lower ice content and micro-lenticular cryostructures (Kanevskiy et al., 2011) suggest syngenetic permafrost aggradation under severe periglacial conditions.

In eastern Beringia, a cold phase approaching glacial conditions was reported in interior Alaska from 39 to 34-33 cal kyr BP, and in northwestern Alaska, from 40 to 35 cal kyr BP (Anderson and Lozhkin, 2001 ) (Fig. 7). July air temperatures ranging around modern values are reported in western Beringia during most part of the Karginsky interval (the western Beringian equivalent of the Middle Wisconsinan, see Supplementary Table 2) (Anderson and Lozhkin, 2001; Elias and Brigham-Grette, 2006). In the central and western areas of western Beringia, Larix forests were relatively common through much of the Middle Wisconsinan (Anderson and Lozhkin, 2001). As for Western Beringia, warmer and moister climatic conditions, and favorable edaphic conditions have led to the expansion of Picea populations in the interior of Yukon (Anderson and Lozhkin, 2001) and could explain the high pollen representation of this taxon prior to $36 \mathrm{kyr}$ BP at the Itkillik site. Under a strong low-pressure atmospheric system, Pinaceae pollen can be transported over thousands of $\mathrm{km}$ and create noise in pollen records (Campbell et al., 1999). However, as chronological control is lacking and as proposed for the lower unit of Ahaliorak Lake located near the study site (Eisner and Colinvaux, 1990), high Picea presence could be related to the Sangamonian interglacial (130-71 kyr BP).

\subsection{Unit 2}

Pollen assemblages in U2 are dominated by Cyperaceae and a higher representation of Sphagnum spores, implying more humid conditions (Ager, 2003). July air temperatures and seasonal air temperature contrast increased, as July sunshine declined. Concomitant decreases in $\delta^{18} \mathrm{O}$ values also support the assertion of a warmer and moister climate during this period. The vegetation is interpreted as a moist Cyperaceae meadow in a low centered ice-wedge polygons landscape. Organic carbon and ice content enrichment across U2 indicate, respectively, environmental conditions favorable for organic matter accumulation and greater moisture availability around $35 \mathrm{kyr}$ BP.

Despite the chronological uncertainties in unit U2, it seems chronologically related to the Middle Wisconsinan interstadial optimum reported across eastern Beringia (Anderson and Lozhkin, 2001). The interstadial was characterized by higher summer insolation than the preceding and following stages. The extent of alpine glaciation was reduced. With higher sea level (60-80 m lower than present), there was more efficient transport of moist air masses from the North Pacific Ocean towards Alaska (Bender, 2013). The significant increase in volumetric ice content (reaching over 75 to $80 \%$ in U2) at the Itkillik site is related to the formation of a buried intermediate layer ( $24 \mathrm{~m}$ b.s.l.), suggesting surface stabilization, vegetation accumulation, and increased ground-ice accumulation (cryostratigraphic unit 6 from Kanevskiy et al., 2011). The climatic reconstruction suggests Itkillik site experienced a warmer interval from 36 to 33.6 cal kyr BP. In agreement with our observations, higher lake levels are reported across interior and northern Alaska between 37.2 and 33 cal kyr BP (Finkenbinder et al., 2015). This is occurring 2-3 kyr prior to the warm interval reconstructed from the Fox permafrost tunnel record in interior Alaska (from 33 to 34 to 30 kyr BP) (Hamilton et al., 1988).

Formation of $\mathrm{U} 2$ was likely triggered by peat accumulation which occurred from 34.8 to 33.6 cal kyr BP (cryostratigraphic unit 5 in Kanevskiy et al., 2011). The peat layers resulted in the significant increase in organic carbon content, representing 40 to $45 \%$ of total carbon. Higher OC contents relate to changes in primary productivity and plant assemblages that are characteristic of Middle Wisconsinan yedoma deposits (Schirrmeister et al., 2013). Peat layers of similar age are described in several yedoma exposures in western Beringia (Tomirdiaro, 1980; Kaplina, 1981; Hopkins, 1982; Tomirdiaro and Chyornen'kiy, 1987) and eastern Beringia (Anderson and Lozhkin, 2001). Peat layers in yedoma sequences are related to buried paleosols indicating interstadial accumulation (Ruhe, 1983) and often can be observed above buried intermediate layers (Gubin, 2002; Kanevskiy et al., 2011).

Similar to climate reconstructions developed for sites located in Interior Alaska and Yukon (Anderson and Lozhkin, 2001), the climate reconstruction of the interstadial optimum from Itkillik suggests a climate that was warmer than during glacial advance episodes but drier than during the Holocene.

\subsection{Unit 3}

The silt accumulation above the peat layer of $U 3$ suggests a return of regional wind erosion, eolian transport and sedimentation which resulted in higher sedimentation accumulation rates (see unit 4 in Kanevskiy et al., 2011). Concurrently, the climate reconstruction and

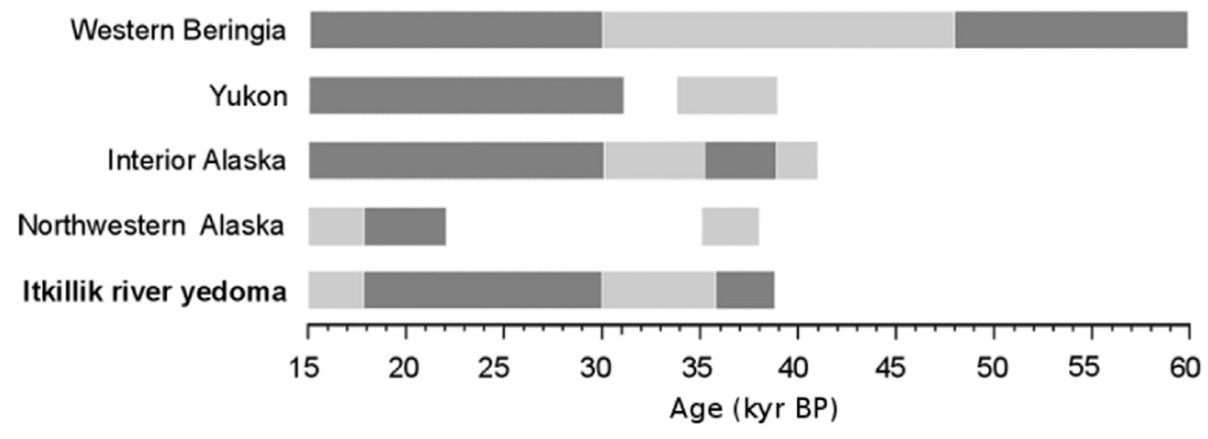

warmer and moister

colder and drier

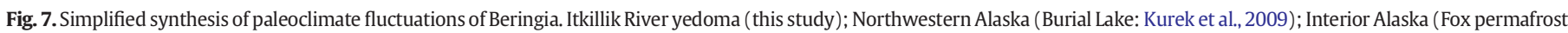
tunnel: Begét, 1990; Anderson and Lozhkin, 2001); Yukon (Anderson and Lozhkin, 2001); Western Beringia (Wetterich et al., 2014). 
isotopic composition during the 33.6-29.8 cal kyr BP interval at the Itkillik site (U3) support the idea of a transition stage towards drier climate conditions. The climate during this period is associated with higher July sunshine value (\%) and greater variability than modern (Fig. 5). Increasing sunshine reconstructed from MAT could be associated with reduced cyclone frequency and therefore strong anticlyclonic atmospheric circulation pattern (Serreze et al., 2000). However, the uppermost buried peat layer at the exposure is aged about $30.4 \mathrm{cal}$ kyr BP and the climate reconstruction suggests that until that time, climate conditions were not as harsh as during the LGM.

\subsection{Unit 4}

The climate reconstructions for the 29.8-17.9 cal kyr BP interval at the Itkillik site show that July air temperatures were on average 2-3 ${ }^{\circ} \mathrm{C}$ colder than modern, with Poaceae and forbs dominating the vegetation, suggesting drier conditions than episodes dominated with Cyperaceae. The $\delta^{18} \mathrm{O}$ values reaching - 30\% are coherent with the pollen-based climate reconstruction pointing that both summer and winter air temperatures were much lower. The dry tundra-dominated environment of Itkillik during the Late Wisconsinan is interpreted as a steppe. Tundra and woody communities are reported in Interior Yukon and southern Alaska over the same period (Anderson and Lozhkin, 2001). Seasonal air temperature contrast is low compared to the previous units. Ice wedges are thinner $(<5 \mathrm{~m})$ than in units 1 to 3 , suggesting conditions favoring faster eolian sedimentation. The sediment column is characterized by high silt and low ice content (cryostatigraphic unit 3 from Kanevskiy et al., 2011). The low seasonal temperature contrast and OC content is indicative of low productivity condition and shorter growing seasons (Anderson and Lozhkin, 2001). High values of July sunshine between 29.8 and 17.9 cal kyr BP suggests increased continentality and thus drier conditions potentially due to lower sea levels during the LGM. The harshest conditions near $30 \mathrm{cal} \mathrm{kyr} \mathrm{BP}$ are related to a rapid lowering of the sea level and glacial advance. Also, perennial sea ice cover (Bartlein et al., 1991) likely prevented the Arctic Ocean from providing moisture to the North Slope of Alaska. Today, winter air temperature and precipitation have the greatest controls on $\delta^{18} \mathrm{O}$ values in Alaska and may explain the large $\delta^{18} \mathrm{O}$ anomalies observed over that interval. However, warmer and moister conditions are observed from $22.2 \mathrm{cal} \mathrm{kyr} \mathrm{BP}$ and could be related to ice retreat following the regional early Itkillik II glaciation advance reported in the Brooks Range (Hamilton et al., 1988).

A cooling episode following the Middle Wisconsinan optimum occurred in Interior Alaska 30-26 kyr BP (Anderson and Lozhkin, 2001). Starting around $30 \mathrm{kyr} \mathrm{BP}$, the increasing extent and thickness of continental ice sheets during the LGM led to a eustatic drop from about $60 \mathrm{~m}$ to about $120 \mathrm{~m}$ lower than present-day sea levels (Clark et al., 2009). Several beetle assemblages from eastern Beringia indicate that LGM mean July air temperatures in Alaska were lower $\left(-1\right.$ to $\left.-4{ }^{\circ} \mathrm{C}\right)$ than modern while western Beringia beetle assemblages suggest July air temperatures as warm as modern (Elias, 2001). A high degree of regional variability among climate reconstructions of eastern Beringia sites make the interpretation of climate difficult; not all fossil assemblages that date to the LGM interval reflect cooling compared to modern temperature averages at the study sites (Elias, 2001).

From $\sim 25.0$ to 17.0 cal kyr B.P., mean July temperatures from Zagoskin Lake and Burial Lake average 2.3 and $3.8{ }^{\circ} \mathrm{C}$ colder than today, respectively (Kurek et al., 2009). Greater continentality across Beringia may explain the main differences between LGM and Holocene climates (Guthrie, 2001). Reconstruction from Viau et al. (2008) based on 47 fossil pollen sites from the North American Pollen Database show that July air temperature was around $4{ }^{\circ} \mathrm{C}$ lower during full glacial conditions. The coldest interval in northern Alaska is related to the early Itkillik II glaciation advance in the Brooks Range from 27 to 21 cal kyr BP (Hamilton, 2003). Burial Lake (355 km south-west of the study site) proxy data indicate xeric and windy conditions in northern Alaska during the LGM (Abbott et al., 2010). Based on Chironomidae assemblages, Kurek et al. (2009) report a $3.5^{\circ} \mathrm{C}$ July air temperature cooling during the LGM in Northern Alaska that matches our July air temperature reconstruction.

\subsection{Unit 5}

Vegetation changed over this period from Poaceae to Cyperaceaedominated and moister conditions comparable to modern ones were taking place. These changes are not accompanied by an increase in woody taxa as observed in other regions of eastern Beringia. Increases in relative abundances of Betula, Salix, Populus, and Ericaceae occurred across eastern Beringia during deglaciation and are related to higher temperatures and precipitation (Ager and Brubaker, 1985). However, presence of peat and Cyperaceae dominance in the upper part of the pollen assemblage is concordant with the modern landscape, essentially colonized by sedges and sparse shrubs.

An abrupt decrease in silt accumulation from 17.1 cal kyr BP (Fig. 2) indicates the end of the Itkillik River yedoma buildup. Similarly, for the Burial Lake site, higher lake level and termination of eolian silt input from 17 cal kyr BP were reported (Abbott et al., 2010). Mann et al. (2002) reported that peat deposition began and shrub vegetation became widespread north of the Brooks Range about $12.5 \mathrm{kyr}$ BP, probably in response to the advent of a warmer and wetter climate. Today, the presence of peat in the Arctic Foothills is widespread. The $\delta^{18} \mathrm{O}$ anomaly values decrease to $>-25 \%$ is concordant with the modern snow ratio (22.3\%; Sloat, 2013). Climate reconstruction and isotopic composition of adjacent ice wedges support the presence of a more seasonally contrasted, warmer and moister climate. Less sunshine could be related to higher cyclonic atmospheric circulation compared to the LGM because of higher sea level that promoted the presence of warmer and moister air mass from the North Pacific. However, we cannot rule out the possibility that lower sunshine may also be due to higher fog coverage. Increased organic carbon content may indicate higher primary productivity. High volumetric ice content at $0.6-1.5 \mathrm{~m}$ b.s.l. is related to the suspended cryostructure typical of the intermediate layer (cryostratigraphic unit 2 from Kanevskiy et al., 2011). The main difference in U2-3 and U5 climates is not the temperature but the aridity.

With only two post-LGM sediment samples, it is not possible to infer from our data climate and ecological changes related to short events such as the last glacial re-advance during the Itkillik II glaciation and the Dryas intervals. The occurrence of modern epigenetic ice wedges (generation IV, Fig. 6) indicates that these ice wedges formed after the deposition of the host sediments (French and Shur, 2010).

\section{Conclusions}

The Itkillik yedoma formed by long distance deposition of eolian sediments. It preserves an important palaeoenvironmental record for northern Alaska that reflects climate and ecological changes over 35 kyr during the Middle Wisconsinan Interstadial and the following Late Wisconsinan glacial advance. Over that period, shifts between Cyperaceae and Poaceae dominance were observed in the pollen spectra. When Cyperaceae were dominant, ice and organic carbon contents were higher locally at the site. When $\delta^{18} \mathrm{O}$ values were similar to modern values, implying warmer and moister conditions, peat aggradation was promoted. Inversely, when Poaceae and other minor taxa were dominant, sediment and ground-ice records indicated drier and colder climate conditions, which promoted silt-rich accumulation. The climate fluctuations timing are consistent with interior Alaska and Yukon records. Similar to interior Alaska, the study site experienced cold conditions before $35 \mathrm{cal} \mathrm{kyr} \mathrm{BP}$ and a following warmer interval until $30 \mathrm{cal}$ kyr BP. The 35 cal kyr BP Middle-Wisconsinan optimum record at Itkillik is in agreement with reports from both interior Alaska and Yukon.

Our study demonstrates the usefulness of combining the use of pollens, carbon and ground ice records yedoma to study Beringia 
paleoenvironments. As for most studies covering the Middle Wisconsinan - Late Wisconsinan time period, uncertainty remains about the chronology of major vegetation and climate shifts. A better understanding of regional atmospheric circulation patterns and edaphic conditions could enhance the quality of interpretations of the ecological heterogeneity across Beringia during the climate fluctuations related to the Wisconsinan glaciation.

\section{Acknowledgment}

This research was supported by Natural Sciences and Engineering Research Council of Canada (RGPIN/05878-2014) (Julie Talbot, Daniel Fortier) and the Faculty of Graduate and Postdoctoral Studies of Université de Montréal (Lyna Lapointe Elmrabti). Jens Strauss acknowledges the German Federal Ministry of Education and Research (grant 01DM12011) and the German National Academic Foundation (Studienstiftung des Deutschen Volkes), ERC grant \#338335, and the Initiative and Networking Fund of the Helmholtz Assoc. (\#ERC-0013) for financial support. Yuri Shur and Mikhail Kanevskiy acknowledge the National Science Foundation (NSF) grant ARC 1023623. Isotope analyses of ground ice were performed by Tim Howe and Norma Haubenstock, Alaska Stable Isotope Facility at the University of Alaska Fairbanks. We would like to thank Daniel Landry for assistance with the pollen extraction methodology, and Anne de Vernal, Olivier Blarquez, Jan Franssen and James King for comments on an earlier draft of this manuscript. We greatly appreciate CH2M HILL Polar Services for their logistical support. Special thanks to Amy Breen and Cody Johnson who collected samples of frozen sediments and wedge ice from the 35-m-high vertical bluff. We also thank Kevin Bjella for participation in the field work at the study site.

\section{References}

Abbott, M.B., Edwards, M.E., Finney, B.P., 2010. A 40,000-yr record of environmental change from burial Lake in Northwest Alaska. Quat. Res. 74:156-165. http:// dx.doi.org/10.1016/j.yqres.2010.03.007.

Ager, T.A., 2003. Late quaternary vegetation and climate history of the central Bering land bridge from St. Michael Island, western Alaska. Quat. Res. 60:19-32. http://dx.doi.org/ 10.1016/S0033-5894(03)00068-1.

Ager, T.A., Brubaker, L.B., 1985. Quaternary Palynology and Vegetational History of Alaska In: Bryant Jr., V.M., Holloway, R.G. (Eds.), Pollen Records of Late-Quaternary North American Sediments. American Association of Stratigraphic Palynologists Foundation, Dallas, pp. 353-384.

Alfimov, A.V., Berman, D.I., 2001. Beringian climate during the late Pleistocene and Holocene. Quat. Sci. Rev. 20:127-134. http://dx.doi.org/10.1016/S0277-3791(00)00128-1.

Anderson, P.M., 1985. Late quaternary vegetational change in the Kotzebue sound area, northwestern Alaska. Quat. Res. 24:307-321. http://dx.doi.org/10.1016/00335894(85)90053-5.

Anderson, P.M., 1988. Late quaternary pollen records from the Kobuk and Noatak river drainages, northwestern Alaska. Quat. Res. 29:263-276. http://dx.doi.org/10.1016/ 0033-5894(88)90035-X

Anderson, P.M., Brubaker, L.B., 1994. Vegetation history of northcentral Alaska: a mapped summary of late-quaternary pollen data. Quat. Sci. Rev. 13:71-92. http://dx.doi.org/ 10.1016/0277-3791(94)90125-2.

Anderson, P.M., Lozhkin, A.V., 2001. The stage 3 interstadial complex (Karginskii/middle Wisconsinan interval) of Beringia: variations in paleoenvironments and implications for paleoclimatic interpretations. Quat. Sci. Rev. 20:91-125. http://dx.doi.org/ 10.1016/S0277-3791(00)00129-3.

Anderson, P.M., Reanier, R.E., Brubaker, L.B., 1988. Late quaternary vegetation history of the black river region in northeastern Alaska. Can. J. Earth Sci. 25:84-94. http:// dx.doi.org/10.1139/e88-009.

Andreev, A.A., Schirrmeister, L., Siegert, C., Bobrov, A.A., Demske, D., Seiffert, M., Hubberten, H.-W., 2002. Paleoenvironmental changes in northeastern Siberia during the late quaternary - evidence from pollen records of the Bykovsky peninsula. Polarforschung 70, 13-25.

Andreev, A.A., Grosse, G., Schirrmeister, L., Kuzmina, S.A., Novenko, E.Y., Bobrov, A.A., Kunitsky, V.V., 2004. Late Saalian and Eemian palaeoenvironmental history of the Bol'shoy Lyakhovsky Island (Laptev Sea region, Arctic Siberia). Boreas 33:319-348. http://dx.doi.org/10.1111/j.1502-3885.2004.tb01244.x.

Bartlein, P.J., Anderson, P.M., Edwards, M.E., McDowell, P.F., 1991. A framework for interpreting paleoclimatic variations in eastern Beringia. Quat. Int. 10:73-83. http:// dx.doi.org/10.1016/1040-6182(91)90041-L.

Begét, J., 1990. Middle Wisconsinan climate fluctuations recorded in central Alaskan loess. Géog. Phys. Quatern. 44:3-13. http://dx.doi.org/10.7202/032793ar.

Bender, M.L., 2013. Paleoclimate (Princeton Primers in Climate). Vol. 9. Princeton University Press, Woodstock, Chapitre, pp. 173-234.
Bigelow, N.H., Brubaker, L.B., Edwards, M.E., Harrison, S.P., Prentice, I.C., Anderson, P.M., Andreev, A.A., Batlein, P.J., Christensen, Torben R., Cramer, W., Kaplan, J.O., Lozhkin, A.V., Matveyeva, N.V., Murray, D.F., McGuire, A.D., Razzhivin, V.Y., Ritchie, J.C., Smith, B., Walker, D.A., Gajewski, K., Wolf, V., Holmqvist, B.H., Igarashi, Y., Kremenetskii, K., Paus, A., Pisaric, M.F.J., Volkova, V.S., 2003. Climate change and Arctic ecosystems: 1 . Vegetation changes north of $55^{\circ} \mathrm{N}$ between the last glacial maximum, mid-Holocene, and present. J. Geophys. Res. 108:817. http://dx.doi.org/ 10.1029/2002JD002558 (D19).

Blaauw, M., Christen, J.A., 2011. Flexible paleoclimate age-depth models using an autoregressive gamma process. Bayesian Anal. 6:457-474. http://dx.doi.org/ $10.1214 / \mathrm{ba} / 1339616472$

Boggs, K., Boucher, T.V., Kuo, T.T., Fehringer, D., Guyer, S., 2012. Vegetation map and Classification: Northern, Western and Interior Alaska. Alaska Natural Heritage Program. University of Alaska, Anchorage (88 p.).

Campbell, I.D., McDonald, K., Flannigan, M.D., Kringayark, J., 1999. Long-distance transport of pollen into the Arctic. Nature 399:29-30. http://dx.doi.org/10.1038/19891.

Carter, L.D. (1988). Loess and Deep Thermokarst Basins in Arctic Alaska. Proceedings of the Fifth International Conference on Permafrost, Tapir Publishers, Trondheim, (2-5 August, 1988), Norway, 706-711.

Clark, P.U., Dyke, A.S., Shakun, J.D., Carlson, A.E., Clark, J., Wohlfarth, B., Mitrovica, J.X. Hostetler, S.W., McCabe, A.M., 2009. The last glacial maximum. Science 325 710-714. http://dx.doi.org/10.1126/science.1172873.

Eisner, W.R., Colinvaux, P.A., 1990. A long pollen record from Ahaliorak Lake, Arctic Alaska. Rev. Palaeobot. Palynol. 63:35-52. http://dx.doi.org/10.1016/0034-6667(90)90005-4.

Elias, S.A., 2001. Mutual climatic range reconstructions of seasonal temperatures based on late-Pleistocene fossil beetle assemblages in eastern Beringia. Quat. Sci. Rev. 20: 77-91. http://dx.doi.org/10.1016/S0277-3791(00)00130-X.

Elias, S.A., Brigham-Grette, J., 2006. Late Pleistocene Glacial Events in Beringia. Encyclopedia of Quaternary Science. Elsevier, London, pp. 1057-1066.

Finkenbinder, M.S., Abbott, M.B., Finney, B.P., Stoner, J.S., Dorfman, J.M., 2015. A multiproxy reconstruction of environmental change spanning the last 37,000 years from burial Lake, Arctic Alaska. Quat. Sci. Rev. 126:227-241. http://dx.doi.org/10.1016/ j.quascirev.2015.08.031.

Fréchette, B., de Vernal, A., Guiot, J., Wolfe, A.P., Miller, G.H., Fredskild, B., Kerwin, M.W. Richard, P.J., 2008. Methodological basis for quantitative reconstruction of air temperature and sunshine from pollen assemblages in Arctic Canada and Greenland. Quat. Sci. Rev. 27:1197-1216. http://dx.doi.org/10.1016/j.quascirev.2008.02.016.

French, H., Shur, Y., 2010. The principles of cryostratigraphy. Earth Sci. Rev. 101:190-206. http://dx.doi.org/10.1016/j.earscirev.2010.04.002.

Froese, D.G., Westgate, J.A., Sanborn, P.T., Reyes, A.V., Pearce, N.J.G., 2009. The Klondike goldfields and Pleistocene environments of Beringia. GSA Today 19:4-10. http:// dx.doi.org/10.1130/GSATG54A.1.

Grimm, E.C., 1987. CONISS: a FORTRAN 77 program for stratigraphically constrained cluster analysis by the method of incremental sum of squares. Comput. Geosci. 13:13-35 http://dx.doi.org/10.1016/0098-3004(87)90022-7.

Gubin, S.V., 2002. Pedogenesis - a component of mechanism of the late Pleistocene ice complex formation. Earth Cryosphere VI (3), 82-91 (In Russian).

Guiot, J., 1990. Methodology of the last climatic cycle reconstruction in France from pollen data. Palaeogeogr. Palaeoclimatol. Palaeoecol. 80, 49-69.

Guiot, J., Gally, Y., 2014. R Package: Bioindic. URL. https://www.eccorev.fr/spip.php? article389.

Guthrie, R.D., 1990. Frozen Fauna of the Mammoth Steppe: The Story of Blue Babe. Chicago University (ISBN: 0226311236, 9780226311234). (323p.).

Guthrie, R.D., 2001. Origin and causes of the mammoth steppe: a story of cloud cover, woolly mammal tooth pits, buckles, and inside-out Beringia. Quat. Sci. Rev. 20: 549-574. http://dx.doi.org/10.1016/S0277-3791(00)00099-8.

Hamilton, T.D., 2003. Surficial Geology of the Dalton Highway (Itkillik-Sagavanirktok Rivers) Area, Southern Arctic Foothills, Alaska. vol. 121. Alaska Division of Geological \& Geophysical Surveys Professional Report, Alaska (32 p.). 10.14509/7191.

Hamilton, T.D., Fulton, R.J., 1994. Middle and Late Wisconsin Environments of Eastern Beringia. In: Bonnichsen, R., Frison, G.C., Turnmire, K. (Eds.), Ice-age Peoples of North America. Texas A\&M University Press, College Station, TX.

Hamilton, T.D., Craig, J.L., Sellmann, P.V., 1988. The fox permafrost tunnel: a late quaternary geologic record in central Alaska. Geol. Soc. Am. Bull. 100:948-969. http:// dx.doi.org/10.1130/0016-7606(1988)100<0948:TFPTAL $>2.3 . C O ; 2$.

Hoefs, J., 2008. Stable Isotope Geochemistry. Springer Science \& Business Media.

Hopkins, D.M., 1982. Aspects of the Paleogeography of Beringia during the Late Pleistocene. In: Hopkins, D.M., Matthews Jr., V., Schweger, C.E., Young, S.B. (Eds.), Paleoecology of Beringia. Academic Press, New York, USA, pp. 3-28.

Juggins, S., 2007. C2 Version 1.5: Software for Ecological and Palaeoecological Data Analysis and Visualisation. University of Newcastle, Newcastle upon Tyne.

Kane, D.L., Youcha, E.K., Stuefer, S.L., Myerchin-Tape, G., Lamb, E., Homan, J.W., Gieck, R.E., Schnabel, W.E., Toniolo, H., 2014. Hydrology and Meteorology of the Central Alaskan Arctic: Data Collection and Analysis, Final Report. University of Alaska Fairbanks, Water and Environmental Research Center, Report INE/WERC 14.05, Fairbanks, Alaska (168 pp.)

Kanevskiy, M., Shur, Y., Fortier, D., Jorgenson, M.T., Stephani, E., 2011. Cryostratigraphy of late Pleistocene syngenetic permafrost (Yedoma) in northern Alaska, Itkillik River exposure. Quat. Res. 75:584-596. http://dx.doi.org/10.1016/j.yqres.2010.12.003.

Kanevskiy, M., Shur, Y., Strauss, J., Jorgenson, T., Fortier, D., Stephani, E., Vasiliev, A., 2016. Patterns and rates of riverbank erosion involving ice-rich permafrost (yedoma) in northern Alaska. Geomorphology 253:370-384. http://dx.doi.org/10.1016/ j.geomorph.2015.10.023

Kaplina, T.N., 1981. History of Permafrost Sediments of Northern Yakutia in Late Cenozoic. In: Dubikov, G.I., Baulin, V.V. (Eds.), History of Developing of Permafrost Sediments of Eurasia. Nauka, Moscow, pp. 153-181 (in Russian). 
Kaplina, T.N., 1986. Regularities of Development of Cryolithogenesis in Late Cenozoic in Accumulation Flood Plain of Northeastern Asia. Summary of Dr Sci Dissertation in Geology and Mineralogy. Permafrost Institute of the Siberian Branch: USSR Academy of Science, Moscow (in Russian).

Kienast, F., Wetterich, S., Kuzmina, S., Schirrmeister, L., Andreev, A.A., Tarasov, P. Nazarova, L., Kossler, A., Frolova, L., Kunitsky, V.V., 2011. Paleontological records indicate the occurrence of open woodlands in a dry inland climate at the present-day Arctic coast in western Beringia during the last interglacial. Quat. Sci. Rev. 30: 2134-2159. http://dx.doi.org/10.1016/j.quascirev.2010.11.024.

Kurek, J., Cwynar, L.C., Ager, T.A., Abott, M.B., Edwards, M.E., 2009. Late quaternary paleoclimate of western Alaska inferred from fossil chironomids. Quat. Sci. Rev.: 1-13 http://dx.doi.org/10.1016/j.quascirev.2008.12.001.

Mann, D.H., Peteet, D.M., Reanier, R.E., Kunz, M.L., 2002. Responses of an Arctic landscape to Lateglacial and early Holocene climatic changes: the importance of moisture. Quat Sci. Rev. 21 (8-9), 997-1021.

Matthews Jr., J.V., 1974. Wisconsin environment of interior Alaska: pollen and macrofossil analysis of a 27 meter Core from the Isabella Basin (Fairbanks, Alaska). Can. J. Earth Sci. 11:828-841. http://dx.doi.org/10.1139/e74-083.

McDowell, P.F., Edwards, M.E., 2001. Evidence of quaternary climatic variations in a sequence of loess and related deposits at Birch Creek, Alaska: implications for the stage 5 climatic chronology. Quat. Sci. Rev. 20:63-76. http://dx.doi.org/10.1016/ S0277-3791(00)00131-1.

Muhs, D.R., Bettis, E.A., 2003. Quaternary loess-paleosol sequences as examples of climate-driven sedimentary extremes. Spec. Pap. Geol. Soc. Am. 370:53-74. http:// dx.doi.org/10.1130/0-8137-2370-1.53.

Murton, J.B., Goslar, T., Edwards, M.E., Bateman, M.D., Danilov, P.P., Savvinov, G.N., Gubin, S.V., Ghaleb, B., Haile, J., Kanevskiy, M., Lozhkin, A.V., Lupachev, A.V., Murton, D.K. Shur, Y., Tikhonov, A., Vasil'chuk, A.C., Vasil'chuk, Y.K., Wolfe, S.A., 2015. Palaeoenvironmental interpretation of Yedoma silt (ice complex) deposition as cold-climate loess, Duvanny Yar, Northeast Siberia. Permafr. Periglac. Process. 26 208-288. http://dx.doi.org/10.1002/ppp.1843.

Nelson, R.E., Carter, L.D., Robinson, S.W., 1988. Anomalous radiocarbon ages from a Holocene detrital organic lens in Alaska and their implications for radiocarbon dating and paleoenvironmental reconstructions in the Arctic. Quat. Res. 29 (1):66-71. http:// dx.doi.org/10.1016/0033-5894(88)90072-5.

Overpeck, J.T., Webb, T.I.I.I., Prentice, I.C., 1985. Quantitative interpretation of fossil pollen spectra: dissimilarity coefficients and the method of modern analogs. Quat. Res. 23: 87-108. http://dx.doi.org/10.1016/0033-5894(85)90074-2.

Reimer, P.J., Bard, E., Bayliss, A., Beck, J.W., Blackwell, P.G., Bronk Ramsey, C., Buck, C.E. Cheng, H., Edwards, R.L., Friedrich, M., Grootes, P.M., Guilderson, T.P., Haflidason, H Hajdas, I., Hatté, C., Heaton, T.J., Hoffmann, D.L., Hogg, A.G., Hughen, K.A., Kaiser, K.F., Kromer, B., Manning, S.W., Niu, M., Reimer, R.W., Richards, D.A., Scott, E.M. Southon, J.R., Staff, R.A., Turney, C.S.M., van der Plicht, J., 2013. IntCal13 and Marine13 radiocarbon age calibration curves $0-50,000$ years cal BP. Radiocarbon 55: 1869-1887. http://dx.doi.org/10.2458/azu_js_rc.55.16947.

Ruhe, R.V., 1983. Depositional Environment of Late Wisconsin Loess in the mid-Continental United States. In: Porter, S.C. (Ed.), Later Quaternary Environments of the United States. University of Minnesota Press, Minneapolis, pp. 130-137.

Sanborn, P.T., Smith, C.A.S., Froese, D.G., Zazula, G.D., Westgate, J.A., 2006. Full-glacial paleosols in perennially frozen loess sequences Klondike goldfields, Yukon territory, Canada. Quat. Res. 66:147-157. http://dx.doi.org/10.1016/j. yqres.2006.02.008.

Sawada, M., Viau, A., Vettoretti, G., Peltier, W.R., Gajewski, K., 2004. Paleoclimate modeldata comparison for 6 ka. Quat. Sci. Rev. 23, 225-244.

Schirrmeister, L., Siegert, C., Kunitzky, V.V., Grootes, P.M., Erlenkeuser, H., 2002. Late quaternary ice-rich permafrost sequences as a paleoenvironmental archive for the Laptev Sea region in northern Siberia. Int. J. Earth Sci. 91:154-167. http://dx.doi.org/10.1007/ s005310100205.

Schirrmeister, L., Froese, D., Tumskoy, V., Grosse, G., Wetterich, S., 2013. Yedoma: late Pleistocene ice-Rich Syngenetic Permafrost of Beringia. Encyclopedia of Quaternary Science, 2nd edition Elsevier, Amsterdam :pp. 542-552 (3888 p.). (ISBN: 978-0444-53643-3). http://dx.doi.org/10.1016/B978-0-444-53643-3.00106-0.

Schirrmeister, L., Meyer, H., Andreev, A., Wetterich, S., Kienast, F., Bobrov, A., Fuchs, M., Sierralta, M., Herzschuh, U., 2016. Late quaternary paleoenvironmental records from the Chatanika River valley near Fairbanks (Alaska). Quat. Sci. Rev. http:// dx.doi.org/10.1016/j.quascirev.2016.02.009.

Serreze, M.C., Walsh, J.E., Chapin III, F.S., Osterkamp, T., Dyurgerov, M., Romanovsky, V. Oechel, W.C., Morison, J., Zhang, T., Barry, R.G., 2000. Observational evidence of recent change in the northern high-latitude environment. Climate Change 46:159-207. http://dx.doi.org/10.1023/A:1005504031923.

Shapiro, B., Cooper, A., 2003. Beringia as an ice age genetic museum. Quat. Res. 60:94-100 http://dx.doi.org/10.1016/S0033-5894(03)00009-7.
Sher, A.V., Kuzmina, S.A., Kuznetsova, T.V., Sulerzhitsky, L.D., 2005. New insights into the Weichselian environment and climate of the east Siberian Arctic, derived from fossil insects, plants, and mammals. Quat. Sci. Rev. 24:533-569. http://dx.doi.org/10.1016/ j.quascirev.2004.09.007.

Shur, Y.L., 1988. The Upper Horizon of Permafrost Soils. Proceedings of the Fifth International Conference on Permafrost. vol. 1. Tapir Publishers, Trondheim: Norway, pp. 867-871.

Shur, Y.L., Jorgenson, M.T., Kanevskiy, M.Z., 2011. Permafrost. In: Singh, V.P., Singh, P., Haritashya, U.K. (Eds.), Encyclopedia of Earth Sciences Series, Encyclopedia of Snow, ice and Glaciers. Springer, Netherlands:pp. 841-848 http://dx.doi.org/ 10.1007/978-90-481-2642-2.

Sloat, A., 2013. Modern to Late Pleistocene Stable Isotope Climatology of Alaska (2014). UNLV Theses/Dissertations/Professional Papers/Capstones. Paper 2143 URL. http:// digitalscholarship.unlv.edu/thesesdissertations/2143.

Strauss, J., Schirrmeister, L. Wetterich, S., Borchers, A., Davydov, S.P. 2012a. Grain-size properties and organic-carbon stock of Yedoma ice complex permafrost from the Kolyma lowland, northeastern Siberia. Glob. Biogeochem. Cycles 26, GB3003. http:// dx.doi.org/10.1029/2011GB004104.

Strauss, J., Shur, Y., Kanevskiy, M., Fortier, D., Bjella, K., Breen, A., Johnson, C., 2012b. Expedition Alaskan North Slope/Itkillik 2012. In: Strauss, J.M., Ulrich, M., Buchhorn, M. (Eds.), Expeditions to Permafrost 2012: Alaskan North Slope/Itkillik, Thermokarst in Central Yakutia, and EyeSight-NAAT-Alaska. Reports on Polar and Marine Research vol. 655. Alfred Wegener Institute for Polar and Marine Research, Bremerhaven, pp. 3-28.

Strauss, J., Schirrmeister, L., Grosse, G., Fortier, D., Hugelius, G., Knoblauch, C., Romanovsky, V.E., Schädel, C., Scheider von Deimling, T., Schuur, E.A.G., Shmelev, D.G., Ulrich, M., Veremeeva, A., 2017. Deep Yedoma permafrost: a synthesis of depositional characteristics and carbon vulnerability. Earth-Sci. Rev. http://dx.doi.org/ 10.1016/j.earscirev.2017.07.007 (in press).

Swanson, D.K., 2006. Biogeographical evidence for the grass (Poaceae) species of Pleistocene Beringian lowlands. Arctic 59:191-200. http://dx.doi.org/10.14430/arctic341.

Tomirdiaro, S.V., 1980. Lyossovo-ledovaya formatsiya Vostochnoy Sibiri v Pozdnem Pleistotsene i Golotsene (Loess-ice Formation of East Siberia During the Late Pleistocene and Holocene). Nauka, Moscow 184 pp. (in Russian).

Tomirdiaro, S.V., Chyornen'kiy, B.I., 1987. Kriogenno-eolovye otlozheniya Vostochnoy Arktiki i Subarktiki (Cryogenic-Eolian Sediments of East Arctic and Subarctic). Nauka, Moscow 196 pp. (in Russian).

Viau, A.E., Gajewski, K., Sawada, M.C., Bunbury, J., 2008. Low-and high-frequency climate variability in eastern Beringia during the past 25, 000 years. Can. J. Earth Sci. 45, $1435-1453$.

Viereck, L.A., Dyrness, C.T., Batten, A.R., Wenzlick, K.J., 1992. The Alaska Vegetation Classification. Department of Agriculture, Forest Service, Pacific Northwest Research Station, Portland, OR, USA, p. 278.

Wetterich, S., Kuzmina, S., Andreev, A.A., Kienast, F., Meyer, H., Schirrmeister, L., Kuznetsova, T., Sierralta, M., 2008. Palaeoenvironmental dynamics inferred from late quaternary permafrost deposits on Kurungnakh Island, Lena Delta, northeast Siberia, Russia. Quat. Sci. Rev. 27:1523-1540. http://dx.doi.org/10.1016/ j.quascirev.2008.04.007

Wetterich, S., Tumskoy, V., Rudaya, N., Andreev, A.A., Opel, T., Meyer, H., Schirrmeister, L., Hüls, M., 2014. Ice complex formation in arctic East Siberia during the MIS3 interstadial. Quat. Sci. Rev. 84:39-55. http://dx.doi.org/10.1016/j.quascirev.2013.11.009.

Whitmore, J., Gajewski, K., Sawada, M., Williams, J.W., Shuman, B., Bartlein, P., et al., 2005. Modern pollen data from North America and Greenland for multi-scale paleoenvironmental applications. Quat. Sci. Rev. 24:1828-1848. http://dx.doi.org/ 10.1016/j.quascirev.2005.03.005.

Willerslev, E., Davison, J., Moora, M., Zobel, M., Coissac, E., Edwards, M., Lorenzen, E.D., Vestergard, M., Gussarova, G., Hail, J., Craine, J., Gielly, L., Boessenkool, S., Epp, L.S., Pearman, P.B., Cheddadi, R., Murray, D., Braten, K.A., Yoccoz, N., Binney, H., Cruaud, C., Wincker, P., Goslar, T., Alsos, I.G., Bellemain, E., Brysting, A.K., Elven, R., Sønstebø, J.H., Murton, J., Sher, A., Rasmussen, M., Rønn, R., Mourier, T., Cooper, A., Austin, J., Möller, P., Froese, D., Zazula, G., Pompanon, F., Rioux, D., Niderkorn, V., Tikhonov, A., Savvinov, G., Roberts, R.G., MacPhee, R.D.A., Gilbert, M.T.P., Kjaer, K.H., Orlando, L., Brochmann, C., Taberlet, P., 2014. Fifty thousand years of Arctic vegetation and megafaunal diet. Nature 506:47-51. http://dx.doi.org/10.1038/nature12921.

Yurtsev, B.A., 1982. Relics of the Xerophyte Vegetation of Beringia in Northeastern Asia. Paleoecology of Beringia. vol. 157, p. 177 .

Zazula, G.D., 2002. Full-Glacial Macrofossils, Paleoecology and Stratigraphy of the Bluefish Exposure, Northern Yukon. Unpublished M.A. Thesis. University of Alberta, Canada (195 p.) 